\begin{tabular}{|c|c|c|c|c|}
\hline \multirow{2}{*}{ (1) } & \multirow{2}{*}{\multicolumn{3}{|c|}{$\begin{array}{l}\text { PORT SAID ENGINEERING RESEARCH JOURNAL } \\
\text { Faculty of Engineering - Port Said University }\end{array}$}} & 11 \\
\hline & & & & \\
\hline
\end{tabular}

\title{
The Impact of Using Smart Architecture on Architectural Creativity
}

\author{
Basma S. Saad ${ }^{1}$ Essam Eldin B. Abou Al-Einen ${ }^{2}$ and Faysal M. Abo El-Azm ${ }^{3}$
}

\begin{abstract}
Smart Architecture is considered as the most prominent aspects of new millennium. It depends on using modern techniques and information technology, working in an integrated manner so that the building performed its function in time. So smart architecture has been identified in terms of its definitions, historical development for the appearance intelligence in buildings, its characteristics and its basic component elements (Smart materials - Smart skin - Smart structure - Smart Systems).

Architecture is not only concerned with physical functions, but it is also concerned with the appearance, formal aspects and its sensational and psychological impact on the human. Therefore the research studies general creativity in terms of its definitions, theories explains it, its fields and how to evaluate it.

The research displays some International examples of smart buildings, to achieve a checklist for the (Functional - Formational - Structural - Technological) elements which must be followed on designing smart building affects positively on creativity in the building. So smart architecture become a mean to achieve a goal. The research also displays some Local examples of smart buildings and compare it with the international ones to increase the awareness of local architects with the latest technology used in this field. This aims to achieve the goal of the research, which is reaching "Smart Creative Building".
\end{abstract}

KEYWORDS: Smart Architecture - Smart Building - Creativity - Creative Architecture - Functional Creativity -Formational Creativity- Structural Creativity -Technological Creativity

\section{INTRODUCTION}

The human aims through technology to control the environment and its changes, by creating a small environment responding to his needs and appropriate to him. So, the recent period of the twentieth century has a great developments in the field of technology and computer use. This made a significant impact on architecture smart architecture definitions appear.

\subsection{Research Problem}

The main problem of the research is the absence of applying creative features on smart buildings in Egypt, as smart buildings is evaluated by the amount of recent technologies used in buildings. So smart architecture became a goal not a task to reach a goal which is constructing creative smart building.

\subsection{Research Question}

The main question of the research is:

"Is smart architecture a goal or is it a task to achieve a goal which is constructing Creative Smart Building?"

\footnotetext{
${ }^{1}$ B. Sc. Architecture Engineering, Faculty of Engineering, Suez, Canal University, Ismailia, Egypt, E-mail: b_s_k_97@yahoo.com

${ }^{2}$ Professor of Architecture and Urban Planning, Vice Dean for Education and Students, Faculty of Engineering, Suez Canal University ، Ismailia Egypt, E-mail: essambadran@gmail.com

${ }^{3}$ Assistant Professor of Architecture and Urban Planning, Faculty of Engineering - Suez Canal University, Ismailia, Egypt,

E-mail:faysal.arch@icloud.com
}

\subsection{Research objectives}

The research's two main aims are as the following:

a) Finding a criteria to evaluate the creativity of smart buildings and also to find the creative features in smart building.

b) Finding how Egyptian architecture deals with the used technologies in Egyptian smart buildings and their effect in creativity.

There are secondary objectives which is concluded in:

a) Defining Smart architecture and Creative architecture.

b) Giving some recommendations that would upgrade Egyptian architecture reaching to creative smart buildings.

\subsection{Research Methodology}

a) Inductive Method

- The research study definitions about smart architecture, its historical backgrounds, its features and the components of the intelligent building.

- The research also study definitions about architectural creativity, theories explained it, its fields and identifying how to evaluate the creativity in the building.

b) Case Study Method

- The research analyzes three international case studies and three local case studies according to the availability of smart architecture's components and evaluate it according to the research's evaluation checklist.

c) Comparison method

- The research compares between the international and local case studies to achieve some recommendations that 
would upgrade Egyptian architecture reaching to creative smart buildings

\section{THEORETICAL APPROACH}

\subsection{Smart Architecture}

Smart building can decide on time, the most effective ways to create an environment and sustainable responsive $\mathrm{e}^{[1]}$, to raise the efficiency of its occupants with the lowest possible costs throughout the life span of the building ${ }^{[2]}$. So it can be defined as ${ }^{[3]}$ :

"The building which accommodates the latest technologies of the age, which make it capable to response the demands of the occupants and adapt internal and external conditions“.

\subsubsection{Historical background}

The origins of architectural intelligence are first explored in old civilizations, starting from the Pharaonic civilization and up to the Islamic civilization in the middle ages.

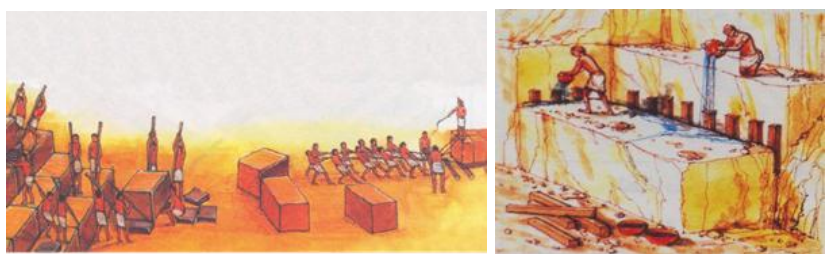

Fig. 1 Using intelligence in moving and cutting stones ${ }^{[4]}$.

Smart buildings in the modern age depend on using computers and artificial intelligence, but smart buildings in ancient civilizations were based on pure and applied sciences like chemistry, physics, mathematics, geography and astronomy.

\subsubsection{Smart architecture generation}

There are three generation for Smart architecture which are as the following ${ }^{[5]}$ :

a) Automated Buildings (1980 -1985).

Buildings that have a group of innovating technology controlled automatically in order to perform its work. There is an example for the buildings in this period as in fig. 2 .

b) Responsive Buildings (1986- 1991).

Buildings that have a group of innovating technology that is able to respond the changeable needs. There is an example for the buildings in this period as in fig. 3 .

c) Effective Buildings (1992 until now).

Buildings that represent responsive environment to achieve its work. There is an example for the buildings in this period as in fig.4.

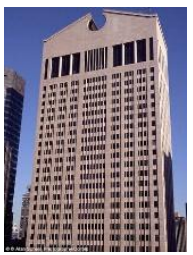

Fig. 2 Telephone and telegraph corporation $^{[6]}$

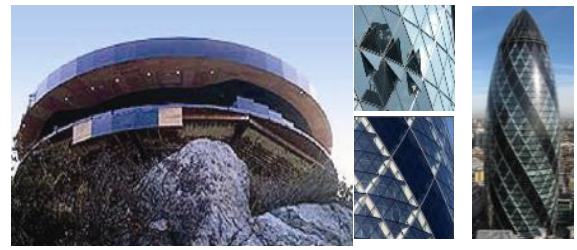

Fig. 3 Rotating home ${ }^{[1]}$
Fig. 4 Swiss re tower building

\subsubsection{Features of smart architecture}

There are three main features for smart architectures appears according to smart architecture generations ${ }^{[3]}$, which are as in the following table:

\begin{tabular}{|c|c|c|c|c|}
\hline Main features & \multicolumn{2}{|c|}{ Secondary Features } & \multicolumn{2}{|c|}{ Check } \\
\hline \multirow{2}{*}{ Automation } & \multirow{2}{*}{\multicolumn{2}{|c|}{$\begin{array}{l}\text { Building management } \\
\text { Communications \& office } \\
\text { automation }\end{array}$}} & $\sqrt{ }$ & \multirow[b]{2}{*}{$\sqrt{ }$} \\
\hline & & & $\sqrt{ }$ & \\
\hline \multirow{4}{*}{ Responsiveness } & \multirow{2}{*}{$\begin{array}{l}\text { Responding } \\
\text { to users' } \\
\text { needs }\end{array}$} & $\begin{array}{l}\text { Limited } \\
\text { response }\end{array}$ & $\sqrt{ }$ & \multirow{4}{*}{$\sqrt{ }$} \\
\hline & & $\begin{array}{l}\text { Smart } \\
\text { response }\end{array}$ & $\sqrt{ }$ & \\
\hline & \multirow{2}{*}{$\begin{array}{l}\text { Responding } \\
\text { to } \\
\text { environmental } \\
\text { changes }\end{array}$} & $\begin{array}{l}\text { Limited } \\
\text { response }\end{array}$ & $\sqrt{ }$ & \\
\hline & & $\begin{array}{l}\text { Smart } \\
\text { response }\end{array}$ & $\sqrt{ }$ & \\
\hline \multirow{5}{*}{$\begin{array}{l}\text { Compatibility } \\
\text { with the } \\
\text { Environment \& } \\
\text { Sustainability }\end{array}$} & \multicolumn{2}{|c|}{$\begin{array}{l}\text { Environmental data } \\
\text { collection }\end{array}$} & $\sqrt{ }$ & \multirow{5}{*}{$\sqrt{ }$} \\
\hline & \multirow{3}{*}{$\begin{array}{l}\text { Efficiency of } \\
\text { the internal } \\
\text { environment }\end{array}$} & Lightning & $\sqrt{1}$ & \\
\hline & & Ventilation & $\sqrt{ }$ & \\
\hline & & Thermal & $\sqrt{ }$ & \\
\hline & \multicolumn{2}{|c|}{ Preservation of energy } & $\sqrt{ }$ & \\
\hline
\end{tabular}

Table 1 Features of smart architecture

\subsubsection{Components of smart architecture}

The spread of the concept of smart buildings leads to the appearance of numerous derivative items, which later became the fundamental components of smart building and also affect the degree of intelligence of the buildings. These components are as the following:

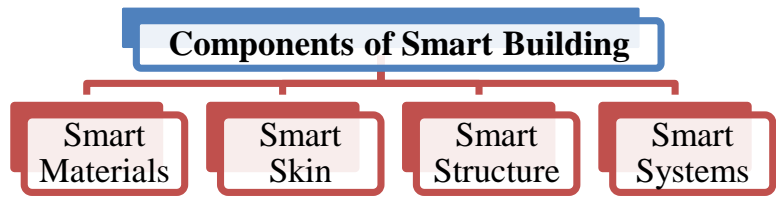

Fig. 5 Components of Smart Building.

a) Smart Materials is distributing some actuators and electronic models through the material, which leads to a major developments in the material properties. Giving it the ability to respond the changes around them and interact with them to be suitable for the functionality that is prepared for it ${ }^{[7]}$, as in fig.6.

b) Smart Skin is integrating sensors and controllers with the outer skin of the building to control the climate 
change inside and outside the building, changing the ordinary skin to climate organizer skin ${ }^{[8]}$, as in fig.7.

c) Smart Structure: is providing the structure systems with sensors and actuators which can decrease undesirable effects or increase the desirable ones ${ }^{[9]}$, as in fig.8.

d) Smart Systems is a set of inputs that are prepared and processed by a certain ways to get to a specific outputs to achieve a certain goals ${ }^{[10]}$, as in fig.9.

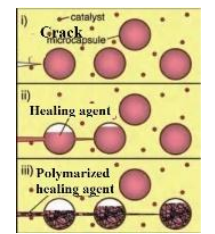

Fig. 6 Self -

Healing material ${ }^{[11]}$

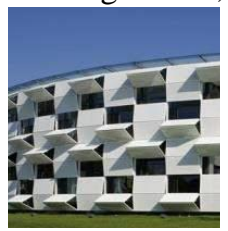

Fig. 7

Showroom-

Kiefer $^{[12]}$

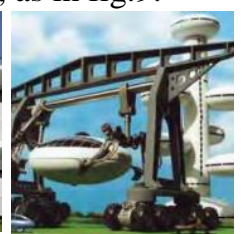

Fig. 8

Automated

construction

equipment

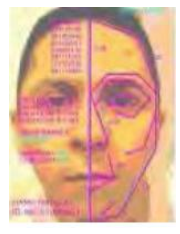

Fig. 9

Identification

Systems ${ }^{[13]}$

\subsection{Architectural Creativity}

There are large number of definitions for creativity, but there is a simple sentence which is the only definition approved by most researchers in this field. This definition is as the following ${ }^{[14]}$ :

"Creativity is the ability to produce work that is Novel and Appropriate"

Such that:

- Novel includes: Innovated - unexpected - Surprising

- Appropriate includes: Useful (Value - Aesthetic) Adjustment Adapted

\subsubsection{Theories about general creativity}

There are four theories explaining general creativity (4P's), which are as the following:

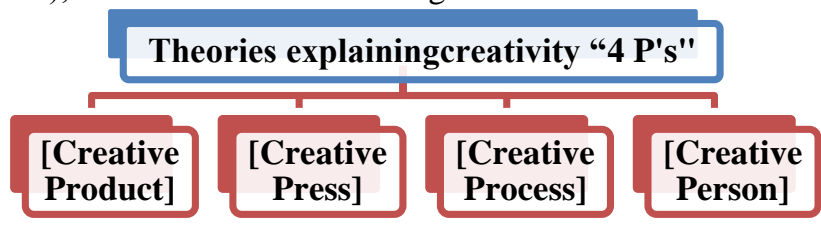

Fig. 10 Theories explaining general creativity

a) Creative Person: Studying the characteristics of creative thinking and a creative person.

b) Creative Process: Studying the steps of creative thinking.

c) Creative Press: Studying environmental factors surrounding the creative person.

d) Creative Product: Studying the main characteristics of creative outputs.

\subsubsection{Features of creative product}

There are five main features describe the creative product or the creative idea in architectural field, which are as the following:

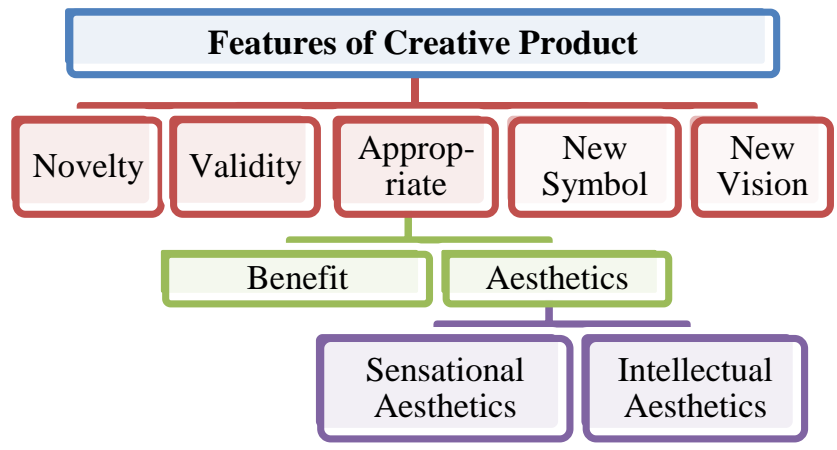

Fig. 11 Features of Creative Product

There are three fundamental features for creative products which are as the following ${ }^{[15]}$ :

a) Novelty: Creative product is unprecedented

b) Validity: Creative product should be executable

c) Appropriate includes two features which are:

- Benefit: Achieving useful benefits either one or more benefits

- Aesthetics which is classified into:

- Sensational: Coming from direct physical sense using the five senses)

- Intellectual: Sensing it after many stages of culture and training)

There are two features not a fundamental features but can be used to raise the level of creativity in creative products which are as the following ${ }^{[16]}$ :

d) New Symbol: Creative product achieve a new symbol of a certain values)

e) New Vision: Creative product can be developed and opens new visions for human experience)

From previous it is concluded the following checklist:

\begin{tabular}{|c|c|c|c|}
\hline $\begin{array}{c}\text { Main } \\
\text { features }\end{array}$ & \multicolumn{2}{|c|}{ Secondary features } & Check \\
\hline \multirow{3}{*}{ Novelty } & \multicolumn{2}{|c|}{ Innovated } & $\sqrt{ }$ \\
\hline & \multicolumn{2}{|c|}{ Surprising } & $\sqrt{ }$ \\
\hline & \multicolumn{2}{|c|}{ Unexpected } & $\sqrt{ }$ \\
\hline \multicolumn{3}{|l|}{ Validity } & $\sqrt{ }$ \\
\hline \multirow{3}{*}{ Appropriate } & \multicolumn{2}{|l|}{ Useful } & $\sqrt{ }$ \\
\hline & \multirow{2}{*}{ Aesthetic } & Sensational & $\sqrt{ }$ \\
\hline & & Intellectual & $\sqrt{ }$ \\
\hline \multicolumn{3}{|l|}{ New Symbol } & $\sqrt{ }$ \\
\hline \multicolumn{3}{|l|}{ New Vision } & $\sqrt{ }$ \\
\hline
\end{tabular}

Table 2 Features of creative product

\subsubsection{Fields of architectural creativity}

There are four fields for architectural creativity which are as the following ${ }^{[16]}$ :

a) Functional Creativity: It specializes in the process of architectural design, solving problems by creative ways.

b) Formational Creativity: Respecting the special composition forms during the process of innovative thinking.

c) Structural Creativity: Formation of internal innovated spaces and external masses using appropriate technology. 
d) Technological Creativity: It means innovation in the technical aspects of the architectural work.

The patterns of each field of creative products are as the following ${ }^{[16]}$ :

\begin{tabular}{|c|c|c|c|}
\hline \multirow{6}{*}{ 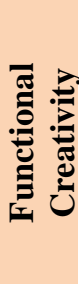 } & Circulation & \multirow{6}{*}{ 预 } & Fulfilment of function \\
\hline & Flexibility & & Lighting, shadow \\
\hline & Lighting & & Scale and Proportion \\
\hline & Ventilation & & Order (Rhythm) \\
\hline & Furniture & & Formal stability \\
\hline & $\begin{array}{l}\text { Security and } \\
\text { Safety }\end{array}$ & & $\begin{array}{l}\text { Integrating with } \\
\text { environment }\end{array}$ \\
\hline
\end{tabular}

\begin{tabular}{|l|l|}
\hline & Stability and balance \\
\hline S & Saffe and Economic \\
\hline & Developing construction equipment technology \\
\hline & Developing building materials technology \\
\hline & Dable 3 Creative patterns of creative fields. \\
\hline
\end{tabular}

\subsubsection{Evaluation of creativity}

There are five levels of creativity which are as the following ${ }^{[16]}$ :

a) Creative product (with the highest value) =

Novelty + Validity + Appropriate [Benefit + Aesthetics

(Sensational + Intellectual) $]+$ New Symbol+ New Vision.

b) Creative product $($ Second Level $)=$

Novelty+ Validity+ Appropriate [Benefit+ Aesthetics

(Sensational or Intellectual)]+ New Symbol + New Vision.

Novelty+ Validity+ Appropriate [Benefit+ Aesthetics (Sensational + Intellectual)]+ New Symbol or New Vision.

c) Creative product $($ Third level $)=$

Novelty+ Validity+ Appropriate [Benefit + Aesthetics (Sensational or Intellectual)]+New Symbol or New Vision.

d) Creative product $($ Fourth level $)=$

Novelty+ Validity+ Appropriate [Benefit+ Aesthetics

(Sensational + Intellectual)]

e) Creative product (with the lowest value) =

Novelty+ Validity+ Appropriate [Benefit + Aesthetics

(Sensational or Intellectual)].

\section{ANALYTICAL STUDIES}

\subsection{Case Study Selection}

Case studies were chosen according to the following:

a) Buildings known for their intelligence, and made a leap in the history of the buildings.

b) Buildings covers the three eras of Smart Architecture generations.

c) Buildings have already been implemented or able to be implemented soon. d) Public buildings in order to verify the application of the ideas of smart architecture on different brands of the buildings and the impact on architectural creativity

\subsection{Case Study methodology}

The main points which are discussed in each case study is as the following:

a) General Information: (Building Name - Date of construction- Dimensions - Location - Function Participants - classification of the building according to the generations of smart architecture - Structural system Materials - History - Description).

b) Characteristics of the building.

c) Features intelligence building.

d) Evaluating the level of creativity for the presented smart components and elements of the building.

e) Defining patterns of creativity in each smart component.

f) Concluding a checklist to evaluate the smart buildings.

\subsection{Evaluation of creativity in smart buildings}

It is concluded from theoretical part the following checklist which helps to evaluate the degree of creativity of smart building, as shown in table:

\begin{tabular}{|c|c|c|c|c|c|c|c|c|c|}
\hline & \multirow{4}{*}{$\begin{array}{l}\text { Components of Smart } \\
\text { Building }\end{array}$} & \multicolumn{8}{|c|}{ Evaluation of Creativity } \\
\hline & & \multirow{3}{*}{ 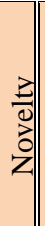 } & \multirow{3}{*}{ : } & \multicolumn{3}{|c|}{$\begin{array}{l}\text { Approp- } \\
\text { riate }\end{array}$} & \multirow{3}{*}{ 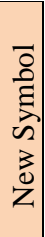 } & \multirow{3}{*}{$\begin{array}{l}0 \\
\frac{0}{0} \\
\vdots \\
3 \\
3 \\
0 \\
z\end{array}$} & \multirow{3}{*}{ ग } \\
\hline & & & & \multirow{2}{*}{ : } & \multicolumn{2}{|c|}{$\begin{array}{l}\text { Aesth } \\
\text {-etics }\end{array}$} & & & \\
\hline & & & & & $\begin{array}{l}\text { D } \\
\stackrel{5}{2}\end{array}$ & $\stackrel{\Xi}{\Xi}$ & & & \\
\hline \multirow{4}{*}{ 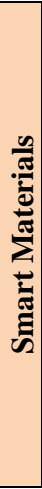 } & $\begin{array}{l}\text { A. Using smart } \\
\text { materials in the } \\
\text { structure }\end{array}$ & $\sqrt{ }$ & $\sqrt{ }$ & $\sqrt{ }$ & $\sqrt{ }$ & $\sqrt{ }$ & $\sqrt{ }$ & $\sqrt{ }$ & \\
\hline & \begin{tabular}{||lr|} 
B. & Using smart \\
& materials in \\
environmental & \\
treatments &
\end{tabular} & $\sqrt{ }$ & $\sqrt{ }$ & $\sqrt{ }$ & $\sqrt{ }$ & $\sqrt{ }$ & $\sqrt{ }$ & $\sqrt{ }$ & \\
\hline & \begin{tabular}{||l} 
C. Using smart \\
materials in the \\
outer envelope
\end{tabular} & $\sqrt{ }$ & $\sqrt{ }$ & $\sqrt{ }$ & $\sqrt{ }$ & $\sqrt{ }$ & $\sqrt{ }$ & $\sqrt{ }$ & \\
\hline & $\begin{array}{ll}\text { D. Using smart } \\
\text { materials in } \\
\text { interior finishing }\end{array}$ & $\sqrt{ }$ & $\sqrt{ }$ & $\sqrt{ }$ & $\sqrt{ }$ & $\sqrt{ }$ & $\sqrt{ }$ & $\sqrt{ }$ & \\
\hline \multirow{5}{*}{ 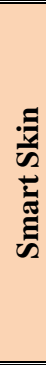 } & $\begin{array}{lll}\text { E. } & \begin{array}{l}\text { Using } \\
\text { facades }\end{array} & \text { smart } \\
\end{array}$ & $\sqrt{ }$ & $\sqrt{ }$ & $\sqrt{ }$ & $\sqrt{ }$ & $\sqrt{ }$ & $\sqrt{ }$ & $\sqrt{ }$ & \\
\hline & F. Using smart roofs & $\sqrt{ }$ & $\sqrt{ }$ & $\sqrt{ }$ & $\sqrt{ }$ & $\sqrt{ }$ & $\sqrt{ }$ & $\sqrt{ }$ & \\
\hline & \begin{tabular}{|l} 
G. Using interactive \\
walls
\end{tabular} & $\sqrt{ }$ & $\sqrt{ }$ & $\sqrt{ }$ & $\sqrt{ }$ & $\sqrt{ }$ & $\sqrt{ }$ & $\sqrt{ }$ & \\
\hline & $\begin{array}{|ll|}\text { H. } \begin{array}{l}\text { Using } \\
\text { shades }\end{array} & \text { smart } \\
\end{array}$ & $\sqrt{ }$ & $\sqrt{ }$ & $\sqrt{ }$ & $\sqrt{ }$ & $\sqrt{ }$ & $\sqrt{ }$ & $\sqrt{ }$ & \\
\hline & $\begin{array}{lll}\text { I. } & \begin{array}{l}\text { Using } \\
\text { windows }\end{array} & \\
\end{array}$ & $\sqrt{ }$ & $\sqrt{ }$ & $\sqrt{ }$ & $\sqrt{ }$ & $\sqrt{ }$ & $\sqrt{ }$ & $\sqrt{ }$ & \\
\hline \multirow{2}{*}{ } & $\begin{array}{lll}\text { J. } & \text { Structural } & \text { Health } \\
\text { and } & \text { Safety } \\
& \text { Monitoring } & \\
\end{array}$ & $\sqrt{ }$ & $\sqrt{ }$ & $\sqrt{ }$ & $\sqrt{ }$ & $\sqrt{ }$ & $\sqrt{ }$ & $\sqrt{ }$ & \\
\hline & $\begin{array}{l}\text { K. Providing stability } \\
\text { and balance using } \\
\text { smart units }\end{array}$ & $\sqrt{ }$ & $\sqrt{ }$ & $\sqrt{ }$ & $\sqrt{ }$ & $\sqrt{ }$ & $\sqrt{ }$ & $\sqrt{ }$ & \\
\hline
\end{tabular}




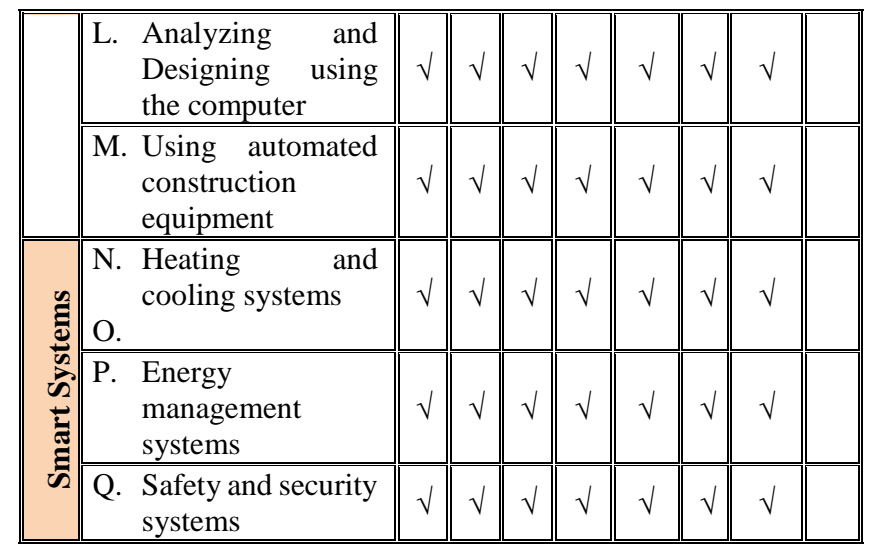

\begin{tabular}{|c|c|c|c|c|c|c|c|c|c|}
\hline & \multirow{4}{*}{$\begin{array}{l}\text { Components of Smart } \\
\text { Building }\end{array}$} & \multicolumn{8}{|c|}{ Evaluation of Creativity } \\
\hline & & \multirow{3}{*}{$\begin{array}{l}\vec{z} \\
\overrightarrow{0} \\
\overrightarrow{0} \\
z\end{array}$} & \multirow{3}{*}{ : } & \multicolumn{3}{|c|}{$\begin{array}{l}\text { Approp- } \\
\text { riate }\end{array}$} & \multirow{3}{*}{ 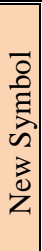 } & \multirow{3}{*}{$\begin{array}{l}0 \\
\frac{0}{2} \\
\vdots \\
z \\
0 \\
z\end{array}$} & \multirow{3}{*}{ d } \\
\hline & & & & \multirow{2}{*}{ 表 } & \multicolumn{2}{|c|}{$\begin{array}{l}\text { Aesth } \\
\text {-etics }\end{array}$} & & & \\
\hline & & & & & $\stackrel{\sim}{0}$ & $\stackrel{\Xi}{\Xi}$ & & & \\
\hline \multirow{5}{*}{ 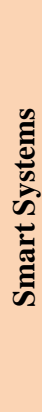 } & $\begin{array}{ll}\text { R. Fire protection } \\
\text { systems }\end{array}$ & $\sqrt{ }$ & $\sqrt{ }$ & $\sqrt{ }$ & $\sqrt{ }$ & $\sqrt{ }$ & $\sqrt{ }$ & $\sqrt{ }$ & \\
\hline & \begin{tabular}{|ll} 
S. & $\begin{array}{l}\text { Communications } \\
\text { systems }\end{array}$ \\
\end{tabular} & $\sqrt{ }$ & $\sqrt{ }$ & $\sqrt{ }$ & $\sqrt{ }$ & $\sqrt{ }$ & $\sqrt{ }$ & $\sqrt{ }$ & \\
\hline & \begin{tabular}{|ll} 
T. & Management of \\
& natural resources \\
Systems
\end{tabular} & $\sqrt{ }$ & $\sqrt{ }$ & $\sqrt{ }$ & $\sqrt{ }$ & $\sqrt{ }$ & $\sqrt{ }$ & $\sqrt{ }$ & \\
\hline & \begin{tabular}{|l} 
U. Industrial lighting \\
systems
\end{tabular} & $\sqrt{ }$ & $\sqrt{ }$ & $\sqrt{ }$ & $\sqrt{ }$ & $\sqrt{ }$ & $\sqrt{ }$ & $\sqrt{ }$ & \\
\hline & $\begin{array}{l}\text { V. Circulation } \\
\text { systems }\end{array}$ & $\sqrt{ }$ & $\sqrt{ }$ & $\sqrt{ }$ & $\sqrt{ }$ & $\sqrt{ }$ & $\sqrt{ }$ & $\sqrt{ }$ & \\
\hline
\end{tabular}

Table 4 Evaluating creativity of smart buildings

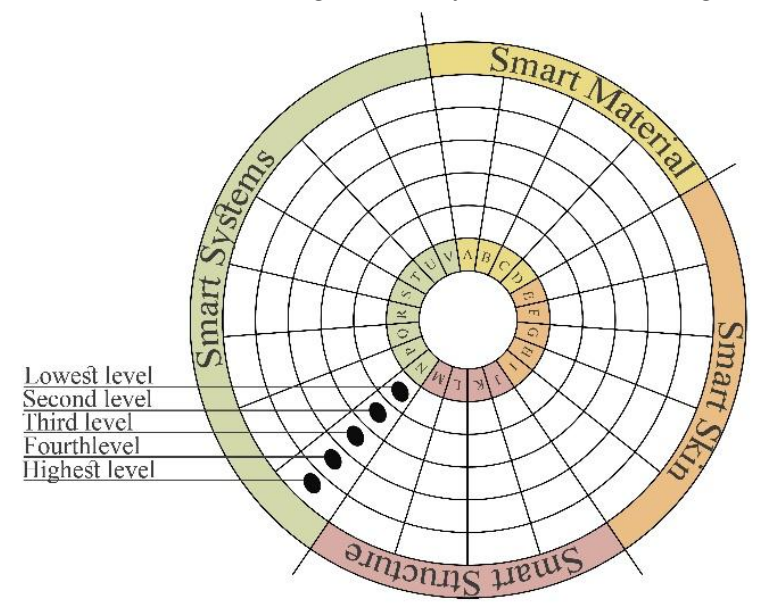

Fig. 12 Determining the level of creativity for each smart components of the smart building.

\subsection{Data analysis}

\subsubsection{International case studies}

There are three International case studies which are as the following:

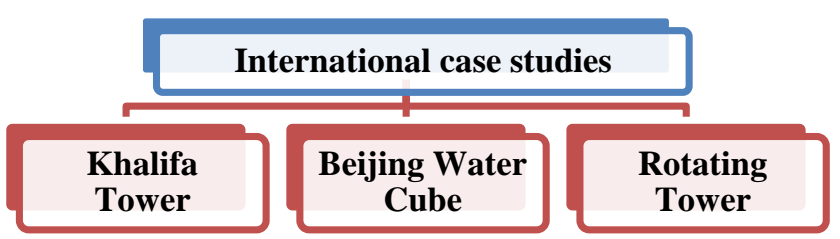

Fig. 13 International case studies

\subsubsection{Khalifa Tower (From 2004 to 2010)}

It is the tallest structure ever built by man in this period that rises $828 \mathrm{~m}$ in Dubai city. It is designed by Adrian Smith and it is also belong to "Effective Buildings" generation of smart architecture ${ }^{[17]}$.

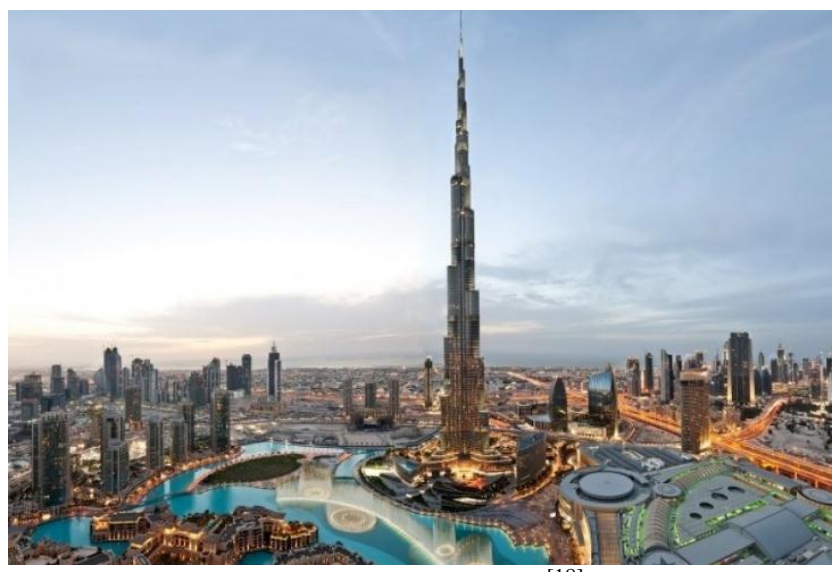

Fig. 14 Khalifa tower ${ }^{[18]}$.

After evaluating the level of creativity of each smart component, it is concluded the following analyzed chart:

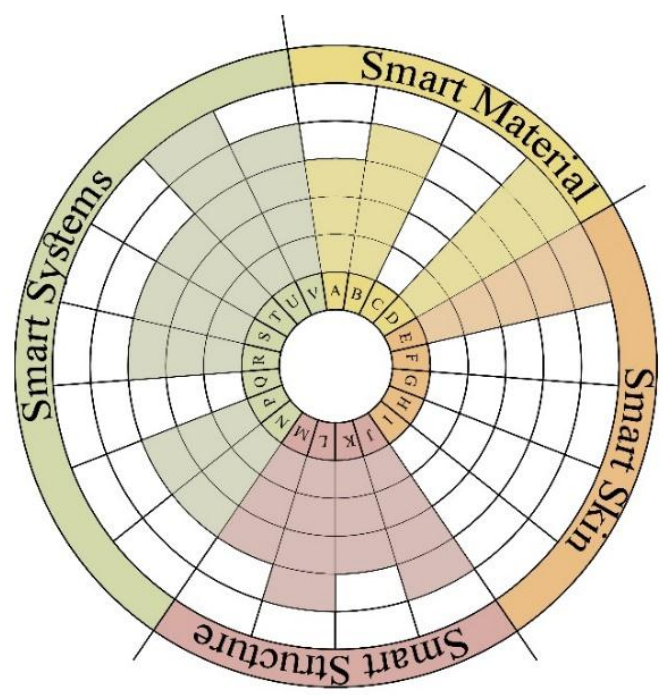

Fig. 15 The level of creativity for the smart components of khalifa tower

\subsubsection{Beijing Water Cube (from 2003 to 2008)}

It is the largest ETFE building structure in the world, in this period that contains 4000 ETFE bubble in Beijing (China). It is designed by Peddle Thorp \& Walker Architects (PTW) with China Construction Design International and it is also belong to "Effective Buildings" generation of smart architecture ${ }^{[19]}$. 


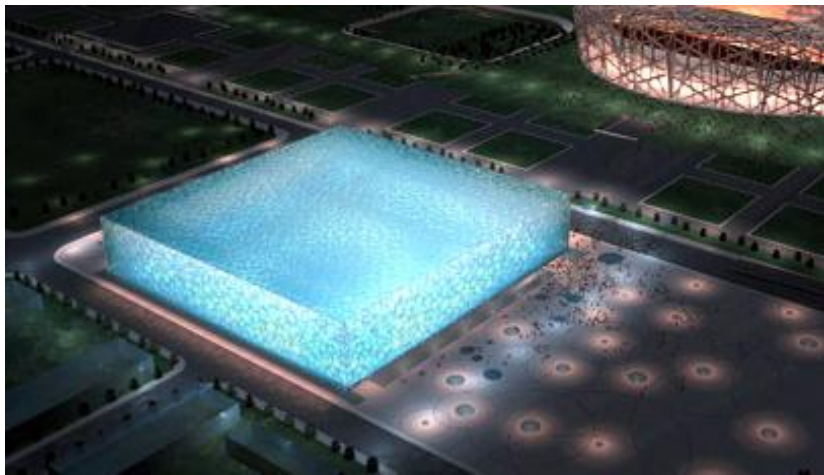

Fig. 16 Beijing Water Cube ${ }^{[19]}$.

After evaluating the level of creativity of each smart component, it is concluded the following analyzed chart:

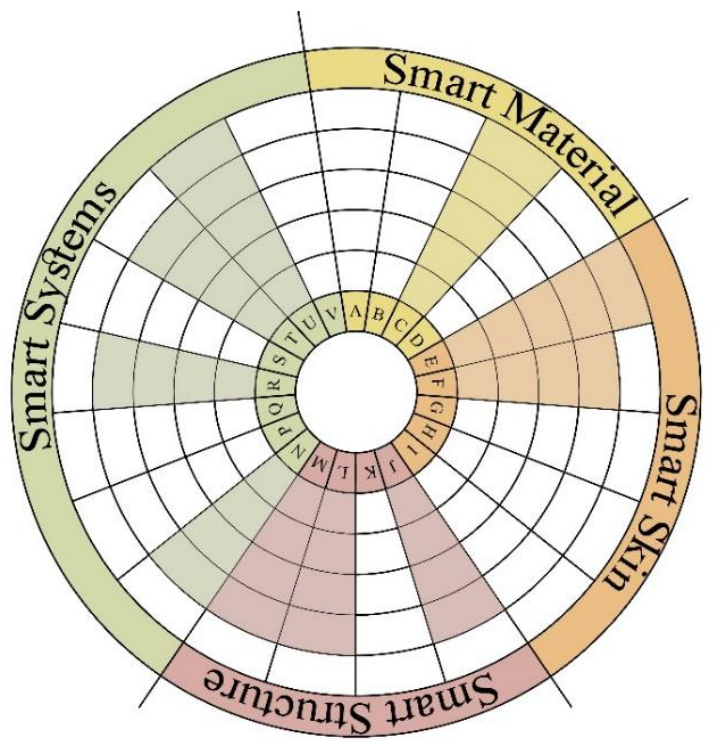

Fig. 17 The level of creativity of Beijing Water Cube.

\subsubsection{Rotating Tower (Undefined period)}

It is the first dynamic and self-energy support tower designed with the prefabricating structure system in this period (period of designing the concept of the tower). As it add the 4rth dimension which is time in consideration through the design phase. It is design to be built in five countries as in Dubai, London, Paris, Moscow and New York. It is designed by David Fisher and it is also belong to "Effective Buildings" generation of smart architecture ${ }^{[21]}$.

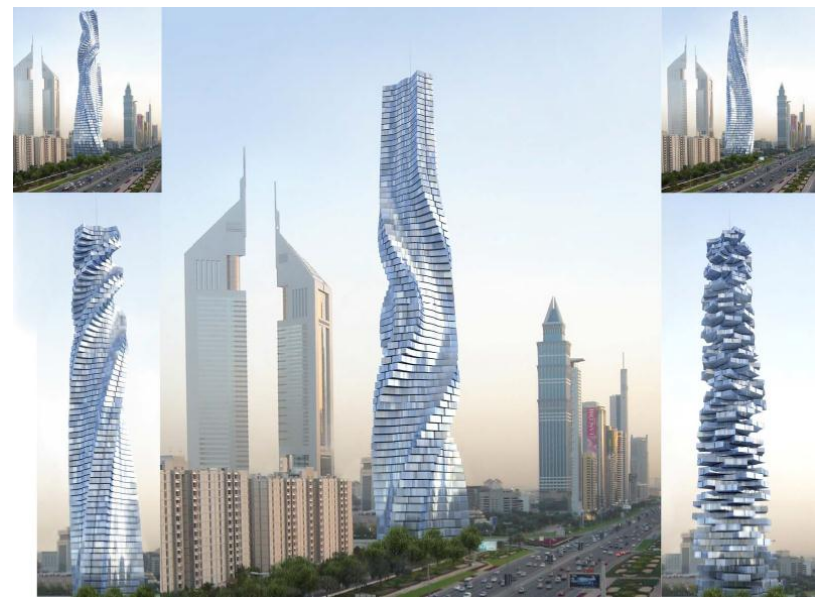

Fig. 18 Dubai Rotating Tower.

After evaluating the level of creativity of each smart component, it is concluded the following analysed chart:

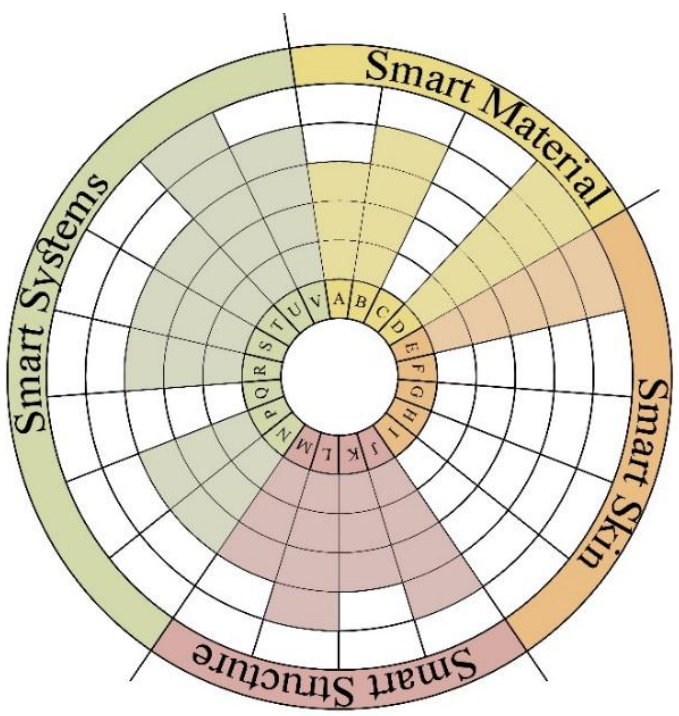

Fig. 19 The level of creativity of rotating tower.

\subsubsection{Local case studies}

There are three Local case studies which are as the following:

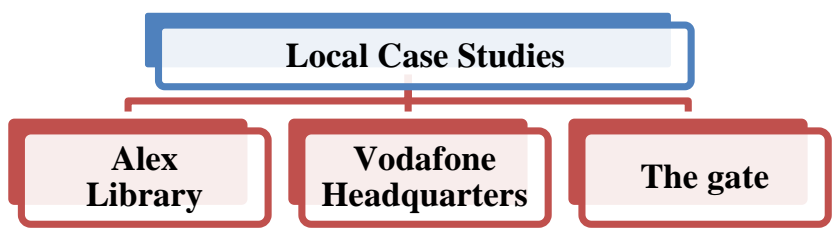

Fig. 20 Local case studies

\subsubsection{Library of Alexandria (from 1995 to 2002)}

The old library considered as the first research center in the world. After its damage the new library is designed by unique form that have a creative philosophical design idea. It is designed by International practice between Mamdouh Hamza office and Snohetta. It is belong to "Effective Buildings" generation of smart architecture ${ }^{[22]}$. 


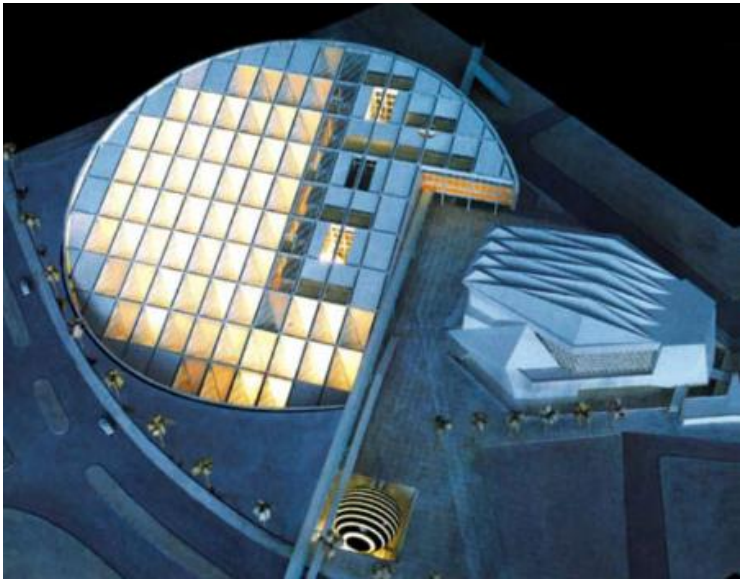

Fig. 21 Library of Alexandria.

After evaluating the level of creativity of each smart component, it is concluded the following analysed chart:

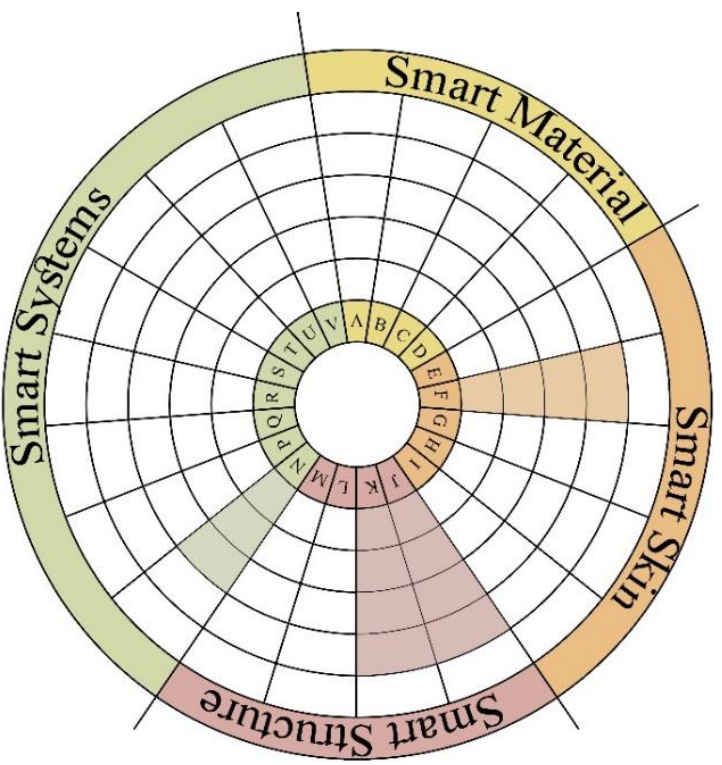

Fig. 22 The level of creativity of Alex Library.

\subsubsection{Vodafone Headquarters (from 2001 to 2004)}

It is designed in the first smart village in Egypt which is supported with large infra structure for internet and communication. It is belong to "Effective Buildings" generation of smart architecture ${ }^{[23]}$.

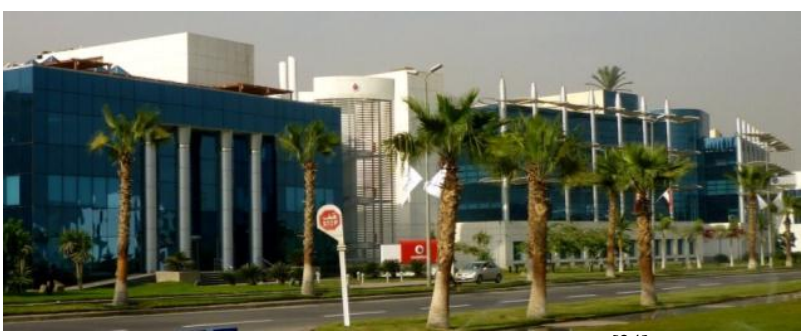

Fig. 23 Vodafone Headquarters ${ }^{[24]}$.

After evaluating the level of creativity of each smart component, it is concluded the following analysed chart:

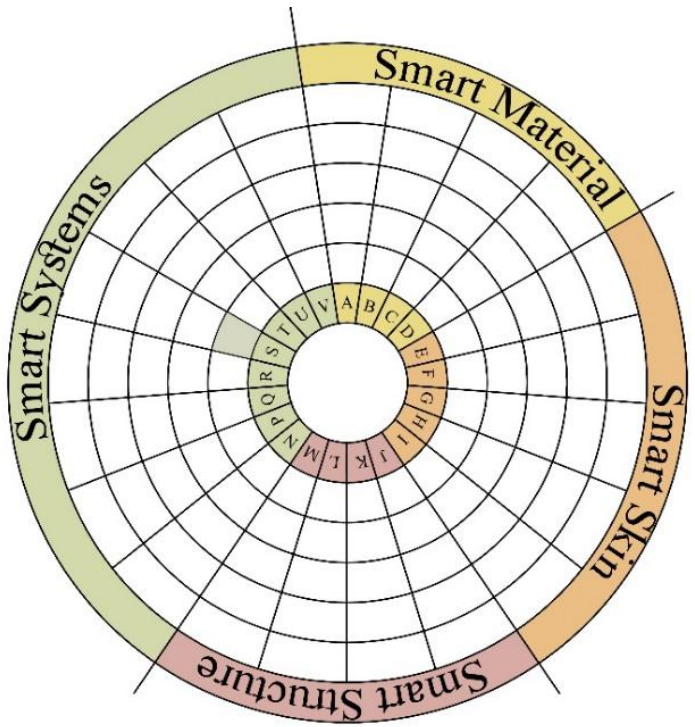

Fig. 24 The level of creativity of Vodafone Headquarters.

\subsubsection{The gate (from 2015 to 2019)}

It is the first smart sustainable residential compound in Egypt. It is designed by Vincent Callebaut and it is belong to "Effective Buildings" generation of smart architecture $^{[25]}$.

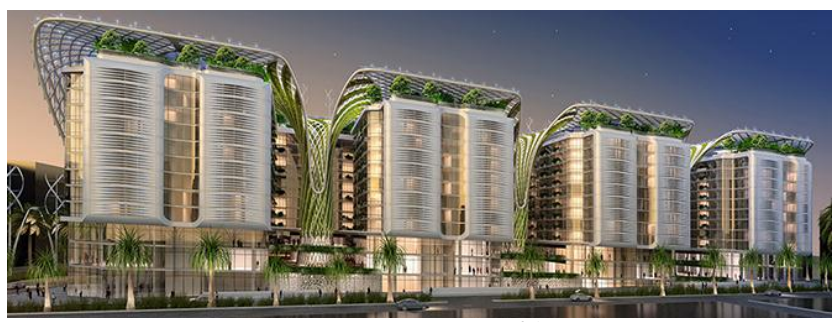

Fig. 25 The gate ${ }^{[25]}$.

After evaluating the level of creativity of each smart component, it is concluded the following analysed chart:

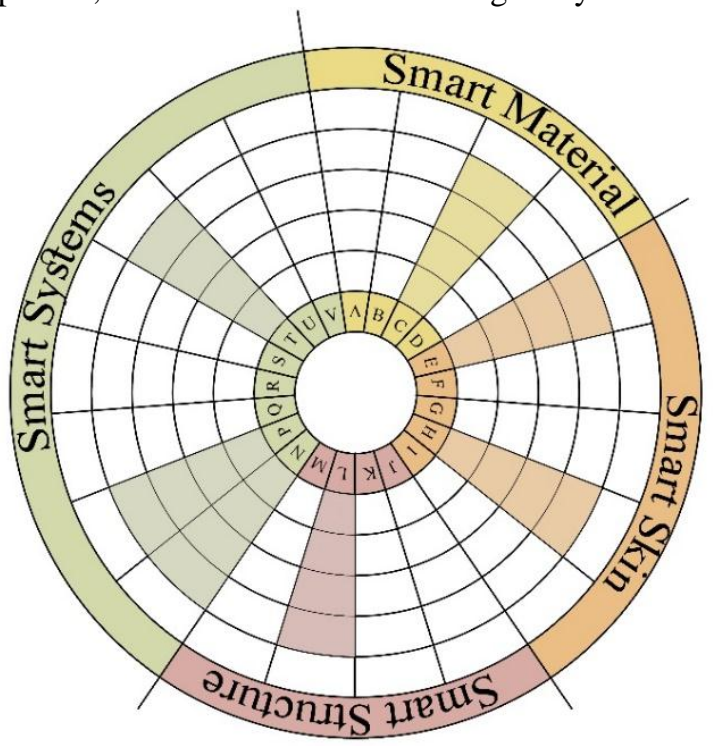

Fig. 26 The level of creativity of the gate 


\subsubsection{Results Discussion}

It is concluded from the comparison between International and Local case studies the following:

During the analytic study of the international case studies, it is concluded that the main purpose of the smart building is to get the highest levels of creativity and overcoming the main challenges of creating a creative building. So smart architecture become a mean to reach a goal which is creating a creative smart building.

$>$ During the analytic study of the Local case studies, it is concluded that the main purpose of the smart building is to get a building with advanced technology and ICT techniques only. It is concluded also how little awareness of the Egyptian architect of what is smart architecture and its goals.

$>$ Two case studies of the local case studies still in the first generation of smart architecture (automation) also it is constructed in the period of the third generation as it depends only on automated systems and advanced communication systems.

$>$ By studying the gate project, it is concluded that the concept of smart architecture in Egypt is developed to include the principles of sustainability and compatibility with the environment. But it still a mimics to the international items not a creative ones. This is a good start to get Egypt to the global level towards a creativity smart buildings in the future.

$>$ By analysing the case studies, it is concluded the creative features in smart buildings which are as the following:

\section{Functional Creativity}

\section{Circulation}

- Using interactive walls and floors which helps in defining the circulation and passages.

Flexibility

- Using internal interactive walls that change its properties according to users' needs.

- Using external interactive walls that change its properties according to environmental data collection.

- Using interactive movable smart partitions.

- The possibility of adding smart systems in the future.

- Using smart systems to change the form of the interior spaces.

\section{Lighting}

Providing natural lighting by:

- Using smart glass in the outer skin of the building which control el degree of passing natural sun light.

- Controlling the transparency of shadings.

- Controlling the transparency of glasses used in smart wall and roofs.

- Using retractable glass roof.

- Using Double Skin Façade

- Using smart windows

- Using smart roofs

Integration between natural and artificial lighting by:
- Using T8 fluorescent lamps and metal halide which switches off gradually depending on the natural lighting.

Providing artificial lighting system by:

- Using artificial lighting responders which switch on and off according to the principle of greater or lesser degree of lighting according to the presence of users.

- Using motion detectors and monitoring devices to determine the level of lighting, movement and adjust the brightness

- Providing control panels on computers screens

- Providing keys (manual) or sensors (automated) to control window opening.

\section{Ventilation}

Providing natural ventilation by:

- Using Double Skin Façade (Box Façade, Shaft Box Façade, Corridor Façade, Multi storey Façade, Louvers Façade)

- Using adaptable smart materials in outer envelope like insulating smart glass, coated smart glass or reflecting smart glass to prevent heat transfer

- Using heat transfer reducing systems like movable curtain walls and automatic opening windows.

- Using air parcel systems.

- Using heating radiators and fans between the double facades for air distribution, which was warmed by the sun.

- Using heating circles in the ground and ceiling

- Using automated fans between the double Skin Façade to allow the exchange of air

- Using automated opening smart windows

Providing artificial ventilation by:

- Controlling ventilation using smart systems

- Using smart responding systems to control ventilation according to number of occupants

- Using smart sensors to collect data about internal and external environmental weather

\section{Security and safety}

Controlling security system by:

- Using surveillance systems as CCTV for entrances and exits.

- Using digital units to detect identity.

- Using Access Card.

- Using Safety and Security systems, programmed according to the remote control.

\section{Fire protection}

Controlling Firing by:

- Using Fire-resistant glass.

- Providing the building with (shelters - sprinklers Smoke discoveries - audible warning signals).

- Using fire protection doors and walls and glass.

- Using automatic fans to expel the smoke.

Interior finishing

- Using new smart materials in interior finishing.

Formational Creativity

Lighting, shadow, color and Texture 
- Using smart skin and controlling its lighting and colors by using computers

- Using of adjustable prismatic plates in the outer skin Order (Rhythm)

- Providing the buildings with automated external moving solar shades.

- Using double skin facades.

Transparency

- Using large percentage of glass depending on the prevailing climate. So the percentage of the openings in the outer skin of the building increase. This will increase the transparency of the building allowing the integration between it and the environment.

\section{Compatibility with the environment}

Formal compatibility with external environmental factors like (Wind- Rain - Earthquakes) by:

- Using automated movable facades, automated movable roof, automated movable shades and automated movable windows which interact with the external environmental factors.

\section{Structural Creativity}

\section{Stability and balance}

- Providing stability using smart elements like smart joints.

- Monitoring vibrations and earthquakes.

Efficient use of building materials

- Using new smart materials in constructions.

Safe and Economic

- Using smart materials in constructions.

\section{Technological Creativity}

Developing construction equipment technology

- Using robots and automated construction equipment.

Developing building materials technology

- Using new smart materials in interior finishing.

- Using new smart materials in environmental treatments.

- Using new smart materials in outer envelope.

- Using new smart materials in constructions

Developing construction design and analysis methods

- Using computer in analyzing Structure systems.

- Developing new computer programs and Structural models design and analysis to present "ComputerBased Analytical Models".

Developing monitoring and maintenance technology

Monitoring

- Structural Health Monitory using smart materials to monitor structural system and to overcome the potential problems. This done by using sensors in the foundations and structural systems.

- Providing air monitoring station in the outer skin of the building to provide the computer with necessary information about the weather.

Maintenance

- Using automated maintenance tools for the outer skin.
- Using self-healing materials to allow easy maintenance.

- Using fiber optics to evaluate damages.

Developing Information technology using computer

Providing integrated communication systems by:

- The building equipped with High-speed wired and wireless connections

- Using automatic exchange sub-centers.

- Using Electronic Mail, Teletext System, Telex \& Teletext Systems, Videotext System, Telephone System, VPN service, local network Video System, video teleconferencing and Firewall.

Controlling the management of the building by:

- Controlling energy systems, natural resources systems, circulation systems

- Controlling Movement and communication elements by using smart elevators and lifts (the evolution of its speed and the ability of accommodating).

- Using mysterious logic that allows programming the computer for what is better as in (ventilation- lighting - fire resistance- control opening)

Table 5 Creative features in smart buildings

\section{CONCLUSIONS}

\subsection{Conclusions}

\subsubsection{Theoretical Conclusions}

From theoretical part it is concluded the following:

- The research identifies definitions of smart architecture and smart building, historical background about the development of the idea of an intelligence in buildings and the development of its generations.

- Three main features are identified, through which the architectural product can be described as smart architecture. These features are automation, responsiveness, and compatibility with the environment \& sustainability.

- The main elements and components of a smart building are as the following: (Smart Materials, Smart Skin, Smart Structure and Smart Systems).

- The research identifies definitions of general creativity and especially architectural creativity, Theories explaining it, its fields, and how to evaluate the architectural products.

\subsubsection{Practical Conclusions}

From analytical part it is concluded the following:

- Smart architecture can be used to overcome the challenges facing the construction of a creative buildings.

- The right use of Smart Architecture preserve the environment and increase the level of creativity of the creative buildings.

- Up until now, there is no local smart creative architecture can compete with or match the international smart creative ones. This is due to the lacks of the knowledge of the correct concept of smart architecture. 
- The Egyptian architects wrong concept of what intelligent architecture is and disregarding its role in rising the degree of creativity of the buildings, made Egyptian architecture lag behind the international progress.

\subsection{Recommendations}

These findings were translated into a group of recommendations addressed to a number of the concerned authorities.

- Introducing new courses in universities specially smart architecture technology and its role in achieving creative buildings

- Increasing the awareness of architects about the right concept of smart architecture that have a positive impact on architectural creativity.

- Doing integrated studies about the environmental and economic aspects, maintenance and operation of smart buildings that have a positive impact on architectural creativity.

\subsection{Future Studies}

The study also proposes future updates to research's findings which are as the following:

- The checklist should be updated whenever other factors affecting the level of creativity in smart buildings.

- Developing the checklist by converting it to a program to evaluate the smart components of smart buildings. This program will give specific proposals for developing of local architecture to achieve the highest possible level of creativity.

The study also proposes a number of future studies which are as the following:

- Studying the possibility of inserting the right definition of smart architecture in the existed buildings that transfer poor smart buildings to creative smart ones.

\section{REFERENCES}

[1] Sherbini, K \& Krowczyk, R. (2004). Overview of Intelligent Architecture. Saudi Arabia: 1st ASCAAD International Conference, e-Design in Architecture, Dhahran.

[2] Wingginton, M. \& Harris, J. (2002) .Intelligent Skins. UK: Architectural Press, an Imprint of Elsevier, Butterworth- Heinemann, Oxford.

[3] Ibrahim, M. A. (2010) .Intelligent Architecture - As an Approach for apply the Technological Development in the Environmental Control and Energy Efficiency in Buildings. Egypt: Master Degree, Faculty of engineering, Cairo University.

[4] Hawas, Z. (2004) .Encyclopaedia of Egyptian pyramids: 4rth generation, historical background.Egypt: Egyptian public printing for books, Cairo.
[5] Harrison, A. et al. (1998) .Intelligent Buildings in South East Asia. UK: Taylor \& Francis, Milton Park, Oxford.

[6] Craven, J. Historic Skyscrapers and High-Rises Retrieved April 3, 2016, from the world wide web: (http://architecture.about.com/od/skyscrapers/ig/Sky scrapers/AT-T-Headquarters.htm)

[7] Brownell, B. (2008). Transmaterial 2: a Catalog of Materials That Redefine OurPhysical Environment. New York: Architectural Press.

[8] Kronenburg, P. (2007). Flexible Architecture That Responds To Change. London: Laurence King Publishing Ltd.

[9] Tzou, H. S. \& Anderson, G. L. (1992). Intelligent Structure System. USA: Kluwer Academic Publishers, Springer Science and Business Media Dordrecht.

[10] Spetzer, E \& Katz, D. (2006). Intelligent Buildings Systems Workshop Design concepts for an intelligent Building system. New York: Syracuse Center of Excellence Syracuse.

[11] White S. R, et al. (February 15, 2001). Autonomic healing of polymer composites. USA: Macmillan Magazines Ltd, Nature, Vol. 409

[12] Showroom Kiefe Technic. Retrieved April 3, 2016, from the world wide web: http://image.architonic.com/imgArc/project1/4/5205027/Ernst-Giselbrecht\%2BPartner-ZTShowroom-Kiefer-Technic-04.jpg

[13] Ali, k. (2008) .The Role of Intelligent Architecture in Supporting. Saudi Arabia: A seminar of Disaster and safety of buildings management, Riyadh.

[14] Sternberg, R. J., \& Lubart, T. I. (1999). The concept of creativity: Prospects and paradigms. UK:Cambridge University Press, Cambridge.

[15] Hassan, N. M. (2008) .The Creativity in Architecture: Concept - pillars - the historical development. Saudi Arabia: Scientific publishing and printing presses, King Saud University.

[16] Abo El-Azm, F.M. (2009) .Creativity in Design of Urban Civil Structures. Egypt: PhD thesis, Faculty of fine arts, Helwan university.

[17] Burj Khalifa, A Seminar report: The award of degree Of Civil. Retrieved April 3, 2016, from the world wide web: www.studymafia.org

[18] Baker, W. F. et al. (2008). Engineering the World's Tallest - Burj Dubai. CTBUH 8th World Congress, Engineered Buildings with the Portland Cement Association.

[19] OstrA Nomination.(2010). Water Cube. Retrieved Octobre 23, 2014, from the world wide web: https://www.iabse.org/Images/Outstanding\%20Stru cture\%20Awards\%20PDFs/OstrA-NominationWaterCube.pdf

[20] PTW Architects. (2008). Water Cube - National Swimming Centre. Retrieved April 3, 2016, from the world wide web: http://www.ptw.com.au/ptw_project/watercubenational-swimming-centre/ 
[21] Fisher, D. H. (March 3-5, 2008) .Rotating Tower Dubai. Dubai: CTBUH 8th World Congress.

[22] Library of Alexandria, Official site Retrieved August 3, 2015, from the world wide web:

(http://www.bibalex.org/en/Page/About)

[23] Smart Villages, Official site Retrieved August 3, 2015, from the world wide web: http://www.smart-villages.com/ar/

[24] Smart Villages, Official site Retrieved August 3, 2015, from the world wide web:

http://www.ecgsa.com/vodafoneheadquarters

[25] Callebaut, V. (2015). The Gate Residence, a Smart Multi-use Complex Cairo Egypt. Retrieved August 3, 2015, from the world wide web:

http://vincent.callebaut.org/page1-img-thegate.html 